\title{
Business Communication Skills
}

\author{
Daniela Cecic Mladinic \\ Universidad de Las Palmas de Gran Canaria, Spain
}

\section{Abstract}

Business Communication Skills is a text book published in 2013 by Maria Esther Rodriguez Gil and Daniela Cecic as authors. The book was envisioned to be used in Business related subjects and as a self- study book. The book offers 6 chapters about Business English: application forms, e-mails, negotiations, CV and cover letter and presentations. It contains readings, exercises and keys. Each chapter has an original reading text adapted for the B1-B2 level purposes. In 2018 it was decided to change and update the information due to some feedback received by the readers. Instead of application forms, we are going to introduce how to make a video CVs and one subchapter related to the use of social media such as Linkedln in order to find a job. The changes are in process and will be presented at this conference for the first time.

Keywords: innovation, learning, business, text book JEL classification: 123

Acknowledgments: The authors and publisher are grateful to the authors and corporations who have given permission for the use of copyright material: Randall $S$. Hansen at Quintessential website, Joshua Malako and Dale Klein and Greg Williams at Enzine website, Laura Stack at Productivitypro website and Gaurav Ghose at Golfnews website.

\section{Introduction}

Business Communication Skills textbook (Cecic, 2013) has been created during a two-year period (2011-2013) firstly by looking for original materials/ articles to be adapted to B1 and B2 levels according to the Common European Framework for Reference CEFR (1991). This descriptive framework highlights the importance of intercultural awareness, lifelong learning and learner's autonomy. Moreover, the student is considered as the centre of learning process and it stresses the essential role of self- assessment (Lenz, 2004). By taking into account all these criteria we have decided to write a book that can be used in class and as a self- study book. In addition, we have followed the CEFR and included a Can do... self- assessment grid of language proficiency outcomes at the end of each unit. Business Communication skills is a comprehensive textbook that offers topics related to real world issues such as CV writing and job interview among others (Richards et al., 2013). After a 5-year period when we have received comments by readers/ users (teachers and students) and therefore decided to update the information scope by including new ways of presenting the CVs: videos and social media but still bearing in mind the CEFR parameters (life skills, learning strategies and competences development). The CEFR document states that learners are supposed to be flexible, meaning being able to cope with the unknown and willing to improve thanks to constant learning since for businesses qualifications are no longer considered sufficient (Berchoud, 2011).

In order to fill in the gap for more student- centred books and for new ways of learning that really cater for job opportunities we will include more self-awareness 
data of own language skills and strategic actions to be taken in order to improve one's learning process. In addition, we will introduce the new ways of presenting one's life achievement via the social media (professional ones such as Linkedln) by more visual presentations such as video CVs.

We also need to mention the concept of a European Qualifications Framework for lifelong learning (EQF) was developed within the "Education and Training 2010" work programme of the European Commission as a meta-framework of reference for educational qualifications as outcomes of lifelong learning. It was published by the Commission as a Staff Working Document in 2005. One of the EFQ's elements is the promotion of the key competences being the following (Martyniuk, 2006, p. 14, 16):

1. Communication in mother tongue;

2. Communication in foreign languages;

3. Mathematical competence and basic competences in science and technology;

4. Digital competence;

5. Learning to learn;

6. Interpersonal, intercultural and social competences, civic competence;

7. Entrepreneurship;

8. Cultural expression

These competences 2, 4, 5, 6, 7 and 8 will be addressed in the new version of Business Communication Skills since they entail the needs of today's worker to be able to perform efficiently and to be able to acquire the skills of lifelong learning. As a new addition to the second version of the book learning to learn, interpersonal and entrepreneurship competences are the main basis of two new chapters dedicated to aid in active job search. Being aware of the digital society and the need to control the information about our own achievements in the labour world the mention of Linkedln in the book seemed like a relevant and necessary information for current job seekers.

Linkedln community membership (www.linkedin.com) has been growing constantly (Gerard, 2011) and therefore to include a guide how to present an efficient and appealing CV on this online social network for professional has been considered a must. Linkedln is probably one of the best performing social media used by human resources management experts, as well as by job seekers (Adams, 2013). One of the main goals in professional career, but as well in private life, is to control and manage the "self-presentation in online communities " (Rui et al., 2013). Presence on social media sites allows its users the improvement of connetions with other members of the network (Schwämmlein et al., 2012; Chiang et al., 2015).

To use Linkedln as a self- representation of our own's best is taking into control our own job history and education to be seen by recruiters. Thus, the core intention behind the chapter related to jobs and CVs has been to show the best practices and examples of how to present oneself in the online professional community.

\section{Methodology}

The methodology behind the Business Communication Skills new version book is Action Research (henceforth AR). AR is a name given to a particular way of looking at your own practice to check whether it is as you feel it should be, and is a form of classroom-based research used by teachers as a means to reflect on possible problems with the view of finding solutions. In this case or data on the book's usage was provided to use by the users themselves (teachers and students). The authors of this book have used the book in their Business classes and contributed to the book's feedback. According to the Longman Dictionary of Language Teaching and 
Applied Linguistics (2013) the main aim of action research is to solve problems in general, and, in particular, in education to look for improvements in teachers' understanding of teaching practice and learning phenomena. AR has several steps as follows: a) the choice of behaviour that the teacher wants to investigate, b) the choice of an appropriate technique; c) data culling and analysis; d) an action plan; e) implementation; and f) improvement; and consequence noting.

AR has its goal to address a specific problem within a specific setting, such as classroom, a workplace, a program, or an organization. By using the action research, we can offer practical solutions in the real world: how to improve the teaching process by implementing changes and improvement (Merriam, 2014). The specific problem was the availability of real life texts and exercises to cater for business communication skills within business English books for English as a Second and/ or Foreign Language.

Although we did not seek for user's feedback, we have received some and therefore decided to investigate the book's content and self- assessment above all. The technique used was the data collection by users and our own class reflections. Once analysed the data the action plan was adopted to address the old-fashioned parts of the book such as application forms and CV writing. The implementation of these changes will be done during the 2018 with the book's second edition. In this second edition, we will explicitly ask for user's feedback by proving an end of book survey in the google doc format. The survey will be anonymous and the collected data will be analysed accordingly.

Moreover, we have used content analysis research method. This investigation technique originated in social science and it is used widely and very often when we want to present data quantitatively: "Content analysis has more than fifty years of use in communication, journalism, sociology, psychology and business. Its methods primarily stem from social and behavioural sciences. It is the fastest growing technique in quantitative research" (Nevendorf, 2002, p. 15).

\section{Results}

The results of the action research and content analysis research conducted throughout a 5-year period have shown that the book needs an update on the content and on the self- assessment criteria. The research conducted by the authors themselves has proven that the book works really well in class and that it is user friendly. The culled data are not quantitative by qualitative and were collected in a rather informal way.

Our main wish was to offer a practical solution to improve teaching/ learning process regarding business skills in real life situations. Nowadays, social media play an important role for job seekers and for those who are looking for potential employees. The information on line can be harmful or helpful therefore it is crucial to control the data available about ourselves. One way of doing this is by offering accurate and updated information on the Linkedln platform and by using CV videos in vogue to present ourselves in the current business world. Linkedln's interface caters towards the need for professional self-promotion (Papacharissi, 2009). Number of Linkedln users was more than 60 million members in 2010 (Hempel, 2010). Visitors to the site have jumped $31 \%$ from last year to 17.6 million in February. "You Google other people, so don't you think they're Googling you?" Linkedln founder Reid Hoffman asks. "Part of a networked world is that people will be looking you up, and when they do, you want to control what they find." Hempel (2010) indicate, "Helping you present yourself well online is just the start. Linkedln plans to go far beyond, making itself an active and indispensable tool for your career path. The secrets lie buried in 
the data: those 60 million profiles, including yours". In order to help our users to control the data available about them the main idea is to offer them strategies, techniques and key words that they can use to boost their careers by using the professional social media network and by using video CVs.

\section{Discussion}

The new and improved edition of Business Communication Skills book available at the end of 2018 is a result of teachers' and author's usage in classrooms and by students themselves. We are aware of the importance of the social media and the tendency to be more visual. Thus, the ways of presenting information in a CV format nowadays is much more acceptable in video format and since the Linkedln allows us to post videos, we can use this tool to our advantage.

Guillory et al. (2012, p. 135) indicate that "compared with traditional resumes, Linkedln resumes were less deceptive about the kinds of information that count most to employers, namely an applicant's prior work experience and responsibilities, but more deceptive about interests and hobbies. The results stand in contrast to assumptions that Internet-based communication is more deceptive than traditional formats, and suggests that a framework that considers deception as a resource for self-presentation can account for the findings".

\section{Conclusion}

In this paper, the new ways of presenting CVs and tools to successfully pass a job interview via the social media have been introduced. The importance of on line communities when looking for a job is undeniable in today's society and the new edition of the book: Business Communication Skills offers some keys and insight into job seekers and job searchers worlds.

Previous research, by using action research method, has shown that students and teachers need the change regarding the way the information has been presented in the book, since they have stated that the chapter about job interviews is oldfashioned and too traditional. For our target audience has expressed the need for a more realistic and updated information the new ways of presenting one's own job history and education have been included in the new edition.

Practical implications of the new chapter will be accountable for in a few years' time once the book has been used in class and as self- study guide book. The research methods - action research method mainly have helped in the writing the new version of the book and the search for academic papers has shown that there is a need for a change the way we have presented our CVs so far. Some authors as shown below confirm the use of Linkedln to find information about job seekers. In addition, these authors also provide information about perceptions created by the professional social media users and those who are recruiting for jobs.

van de Ven et al. (2017) indicate that it is "clear that recruiters regularly use jobrelated social networking sites such as Linkedln in their screening of candidates, people are likely to post information more deliberately on job-related social networking sites like Linkedln than they do on social networking sites like Facebook".

While students are likely aware their online identities can be, and probably are, being viewed, they may not know the extent to which their on-line presence is being used for evaluation and job fit, or how the recruiter's perception may differ from their own with regard to a social media post (Alexander et al., 2017, 241).

The limitations of this study lie in the fact that the success and acceptance of the changes and the use of the new information is not going to be available for some 
years since the book has to be used for some time by students and by teachers. To enhance the target audience feedback an end question list will be included by using the Google doc survey (an anonymous one) to ensure real and accurate information and the search for even bettering book quality.

\section{References}

1. Adams, S. (2013), "New survey: Linkedln more dominant than ever among job seekers and recruiters, but Facebook poised to gain", Forbes, Vol. 10, No. 5, pp. 28-29.

2. Alexander, E. C., Mader, D., Mader, F. H. (2017), Using Social Media During the Hiring Process: A Comparison Between Recruiters and Job Seekers. Attlantic Marketing Association Proceedings. Available at https://digitalcommons.kennesaw.edu/ama_proceedings/2017/MKTGEDU_T09/1/ (11 July 2018)

3. Berchoud, M. (2011), Pathways through assessing, learning and teaching in the CEFR, Council of Europe. European Centre for Modern Languages. Available at: http://ecep.ecml.at/Portals/26/training-kit/files/2011_08_29_ECEP_EN.pdf 11 July 2018)

4. Cecic, D. (2013), "Business Communication Skills". Available at: https://www.webknjizara.hr/knjige/prirucnici/business-communication-skills-danielacecic (11 July 2018)

5. Chiang, J. K. H., Suen, H. Y. (2015), "Self-presentation and hiring recommendations in online communities: Lessons from Linkedln", Computers in Human Behavior, Vol. 48, pp 516-524.

6. Gerard, J.G. (2011), "Linking in with Linkedln: Three exercises that enhance professional social networking and career building", Journal of Management Education, Vol. 36 No.6, pp. 866-897.

7. Guillory, J., Hancock, J. T. (2012), "The effect of Linkedin on deception in resumes", Cyberpsychology, Behavior, and Social Networking, Vol. 15 No.3, pp. 135-140.

8. Hempel, J. (2010), "How Linkedln will fire up your career", Fortune, 4(12), 2010. Available at: http://archive.fortune.com/2010/03/24/technology/linkedin_social_networking.fortun e/index.htm (1 1 July 2018)

9. Lenz, P. (2004), "The European Language Portfolio", in Morrow, K. (Ed.), Insights from the Common European Framework, Oxford University Press, Oxford, pp. 22-31.

10. Martyniuk, W. (2006), "European Frameworks of Reference for Language Competences", in Language Policy Division, Intergovernmental Conference Languages of Schooling: toward a Framework for Europe, 16-18 October 2006, Strasbourg.

11. Merriam, S. B. (2014), Qualitative Research: A Guide to Design and Implementation, New Jersey, NJ: John Wiley \& Sons.

12. Neuendorf, K. A., Kumar, A, (2002), "Content analysis", The International Encyclopedia of Political Communication, Vol. 1, pp. 221-230.

13. Papacharissi, Z. (2009), "The virtual geographies of social networks: a comparative analysis of Facebook, Linkedln and ASmallWorld", New Media \& Society, Vol. 11 No.12, pp. 199-220.

14. Richards, J. C., Schmidt, R. W. (2013), Longman dictionary of language teaching and applied linguistics, Routledge

15. Rui, J., Stefanone, M. A. (2013), "Strategic self-presentation online: A cross-cultural study", Computers in Human Behavior, Vol. 29, No. 1, pp. 110-118.

16. Schwämmlein, E., Wodzicki, K. (2012), "What to tell about me? Self-presentation in online communities", Journal of Computer-Mediated Communication, Vol. 17, No. 4, pp. 387-407.

17. van de Ven, N., Bogaert, A., Serlie, A., Brandt, M. J., Denissen, J. J. (2017), "Personality perception based on Linkedln profiles", Journal of Managerial Psychology, Vol. 32 No. 6. pp. 418-429. 


\section{About the author}

Daniela Cecic Mladinic got her PhD in Teacher Training and Applied Linguistics, Master in Secondary Education and Educational Processes, BA in English Philology, Certificate of English teaching to adults by the University of Cambridge, Certificate of Business English teaching by the London Chamber of Commerce. Co-author of the book Business Communication Skills, lecturer on foreign language teaching and learning at international conferences, participation in two European Community projects and one for the Ministry of Education on the teaching of foreign language subjects and the creation of the methodology book. Coordinator of the British Council examinations IELTS for the Canary Islands and professor of business English in companies. Universidad de Las Palmas de Gran Canaria ULPGC lecturer at the teacher training degree and master level. MBA Business School- director of studies. The author can be contacted at daniela.cecic@ulpgc.es 